FLORA NOVAE ANGLIAE 


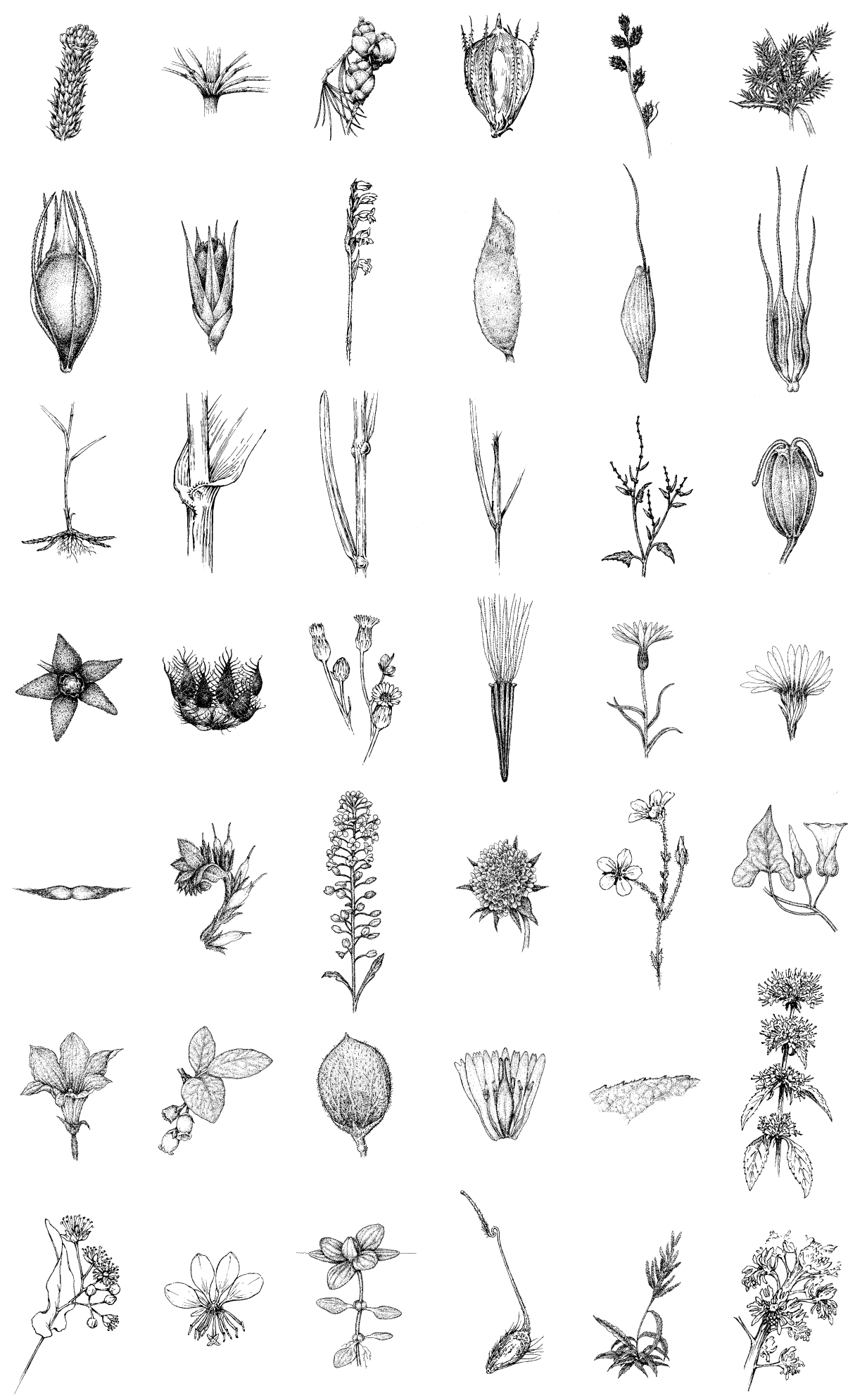


New England Wild Flower Society's

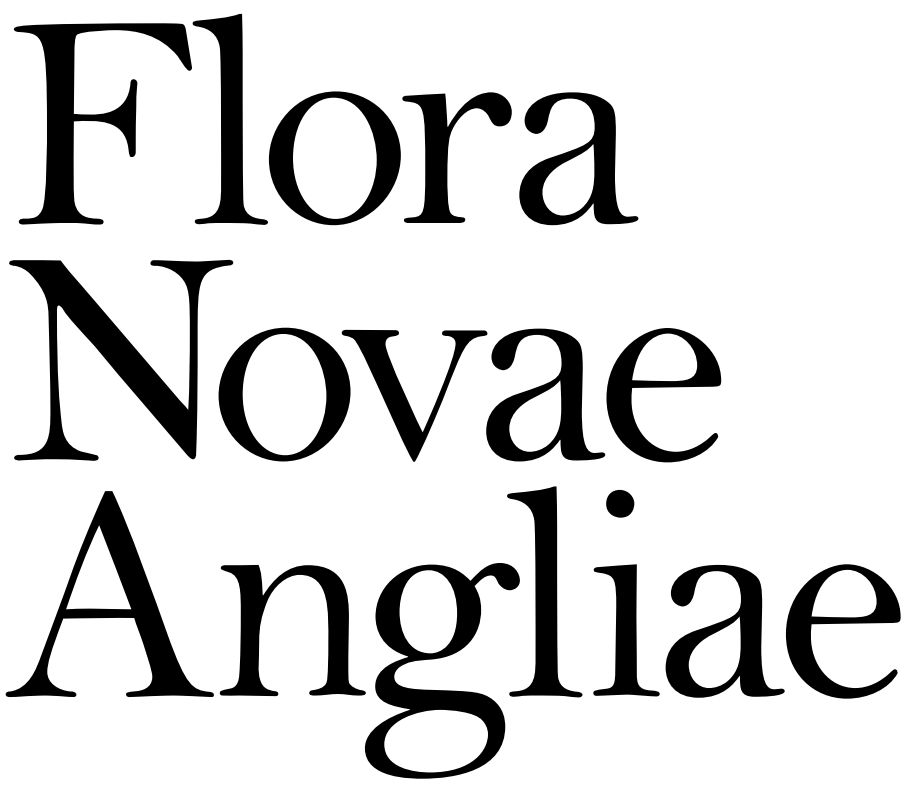

A Manual for the Identification

of Native and Naturalized Higher Vascular Plants

of New England

\section{Arthur Haines}

Illustrated by Elizabeth Farnsworth

and Gordon Morrison

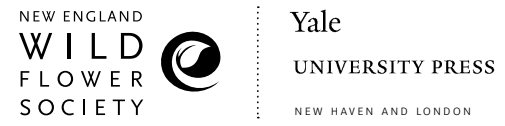


This book is dedicated to the Standing People.

hic est res secretissima quam nemo novit, (radix radicis et gemma gemmae hic est et caelum caeli arboris vitae dictae; quae crescit altior quam anima sperare potest aut animus abdere potest) et hoc est miraculum quod stellas separat tuum cor gero (id gero in corde meo)

The mission of New England Wild Flower Society is to conserve and promote the region's native plants to ensure healthy, biologically diverse landscapes. Founded in 1900, the Society is the nation's oldest plant conservation organization and a recognized leader in native plant conservation, horticulture, and education.

Copyright $(2) 2011$ by the New England Wild Flower Society.

All rights reserved. This book may not be reproduced, in whole or in part, including illustrations, in any form (beyond that copying permitted by Sections 107 and 108 of the U.S. Copyright Law and except by reviewers for the public press), without written permission from the publishers.

Yale University Press books may be purchased in quantity for educational, business, or promotional use. For information, please e-mail sales.press@yale.edu (U.S. office) or sales@yaleup.co.uk (U.K. office).

Library of Congress Control Number: 2011922019

ISBN 978-0-300-17154-9 (hardcover : alk. paper)

A catalogue record for this book is available from the British Library.

This paper meets the requirements of ANSI/NISO Z39.48-1992 (Permanence of Paper).

Printed in the United States of America. 